原著＼cjkstart振動障害患者の体性および自律神経機能

$$
\begin{gathered}
\text { 佐々木 秀 行*, 菊 岡 弘 芳*, 江 本 正 直* } \\
\text { 宮 村 } \\
\text { 敬* }
\end{gathered}
$$

\title{
PERIPHERAL SOMATIC AND AUTONOMIC NERVE FUNCTIONS IN PATIENTS WITH OCCUPATIONAL VIBRATION DISEASE
}

\author{
Hideyuki SaSAKI,* Hiroyoshi KikUoKa,* Masanao Emoto* \\ and Kei MIYAMURA*
}

In order to evaluate the functions of the peripheral somatic nerve and autonomic nerve in patients with occupational vibration disease objectively and quantitatively, four examinations were performed on twenty 44-63 yr old patients with occupational vibration disease and their total operating time ranged from 5,000 to $43,750 \mathrm{~h}$.

1) Motor nerve conduction velocities (MCV) and sensory nerve conduction velocities (SCV) of the ulnar and median nerves were measured using conventional methods.

2) Electrogustatory thresholds under the controlled area of the chorda tympani nerve were measured by Tomita's method using an electrogustometer (610-M, M.E.C.).

3) Dopamine- $\beta$-hydroxylase (DBH) activity in blood was assayed by the photometric assay of Nagatsu and Udenfriend.

4) Coefficient of variation of R-R interval in ECG ( $\left.C V_{R-R}\right)$ was measured after 15-min-resting in supine position by using a $R-R$ interval analyzer (Autonomic $R 100$, M.E.C.).

The results of these examinations were compared with those of special examinations for the diagnosis of vibration disease.

In patients with occupational vibration disease, $\mathrm{MCV}$ and SCV of the ulnar and median nerve were lower in value than those in age-matched healthy controls. In particular, MCV of the ulnar nerve, MCV and SCV of the median nerve were significantly lower in the patients than in the controls. Nerve conduction velocities were significantly correlated with skin temperature and nailpress test, though diminished nerve conduction velocities observed in vibration disease patients were considered to be attributable to peripheral circulatory disturbance.

Electrogustatory thresholds under the controlled area of the chorda tympani nerve in the patients were significantly higher than those in age-matched healthy controls, suggesting that the gustatory function was disturbed in patients with vibration disease.

DBH activities in patients with vibration disease were significantly higher than those in healthy controls, suggesting that the sympathetic nerve function was accelerated in the patients.

CV R-R in the patients was significantly lower than in age-matched healthy controls. It was suggested that the function of the parasympathetic nerve (especially the cardiac branch of vagus) was decreased in patients with vibration disease.

These findings suggest that these examinations are useful in elucidating the pathogenesis of vibration disease.

Key words: nerve conduction velocity; vibration disease; electrogustatory threshold; serum dopamine- $\beta$-hydroxylase activity; variation coefficient; R-R interval ; ECG

\footnotetext{
*和歌山県立医科大学第一内科

昭和 61 年 3 月 3 日受付

* The First Department of Medicine, Wakayama University of Medical Science

Received for publication, March 3, 1986
} 


\section{I.はじめに}

振動障害はレイノー現象を特徵的な症状とする.振動 工具を長期間使用することによって生ずる職業性疾患で あり，1911 年の Loriga の報告をはじめとし，わが国で は1965年頃より“白ろら病”上いう名で社会的にも注 目されるようになった。当初，本疾患は手指のレイノー 現象に象㑽される末梢循環障害や，知覚異常を主体とす る末梢神経障害のみが強調されていたが，近年，中权神 経系, 自律神経系, 筇肉系, 骨関節系, 内分泌系に障

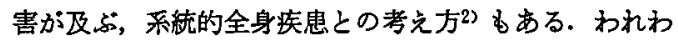
れは，比較的客観的，定量的な四つの検查法を用いて振 動障害患者の末梢体性神経機能拉よび自律神経機能の評 価を試みた. 従来、末梢神経障害の評価は上肢とくに手 関節より末梢にみられる自覚的な知覚異常にたよるとこ ろが大きかった. 今回は客観的, 定量的評価が可能な運 動神維伝導速度 (motor nerve conduction velocity, $\mathrm{MCV}$ ), 知覚神経伀導速度 (sensory nerve conduction velocity, SCV) を正中神経および尺骨神経においてて测定 した. 電気味覚検查 (electrogustometry) は電気刺激に よる味を自覚する域値を湘定することにより味覚機能を 定量的に評価できるるので味覚の機能検查法として臨床 的に応用されている32. そこで，振動障害患者に対して， 政索神経領域の電気味覚検査を施行した。自律神経系の らち交感神経系は主として交感神経末端より放出され神 経活動の指標となると考えられている dopamine- $\beta$ hydroxylase (DBH) を測定した. 副交感神経系の機能 検查としては，心電図 R-R 間隔の変動係数 (coefficient of variation of $R-R$ interval, $C V_{R-R}$ ) を剆定した. こ の $\mathrm{CV}_{\mathrm{R}-\mathrm{R}}$ は 1973 年に Wheeler \& Watkins ${ }^{4}$ が精尿 病性自律神経障害で心電図上の R-R 間隔の変動が減少 することを報告して以来, 副交感神経, 特に迷走神経心 缄枝の機能の定量的検查法と考えられている5 .

以上の四つの検査より得られた成續は，“振動工具の 取扱い業移に保る特殊健康診断”6)（以下特殊健診之略 す）で得られた検査成績とも比較検討し，若干の知見を 得たのでここに報告する.

\section{II. 対象・方法}

対象はチェンソーの長期間使用によりレイノ一現象が 出現し，職業性の振動障害と認定され，国保すさみ病院 に通院加療中の男性患者 20 名 (以下対象患者とする). 1983 年 10 月時点の年路令は $44 \sim 63$ 歳, 平均 55.3 歳. 振 動工具の粉取扱い時間 (total operating time, TOT) は $5,000 \sim 43,750$ 時間, 平均 16, 170 時間. 振動工具の使
Table 1. Subjective symptoms of patients with vibration disease $(n=20)$.

\begin{tabular}{lcr}
\hline Subjective symptoms & $N$ & $\%$ \\
\hline White finger attack & 17 & 85 \\
$\begin{array}{l}\text { Numbness or paresthesia } \\
\text { of hands }\end{array}$ & 20 & 100 \\
Stiffness of hands & 20 & 100 \\
Pain in hands or arms & 19 & 95 \\
Pain in neck & 20 & 100 \\
Shoulder stiffness & 17 & 85 \\
Headache or head heaviness & 19 & 95 \\
Vertigo & 12 & 60 \\
\hline
\end{tabular}

用年数は 10 25 年, 平均 15.2 年間. 振動工具使用中止 後の年数は $1 \sim 8$ 年, 平均 5.6 年間である. 自覚症状は Table 1 亿示すと扣りであり多殿な症状が高頻度にみら れ，1984 年においても $85 \%$ の患者にレイノ一現象がみ られている.また，これら対象患者は，栯尿病，慢性肺 疾患，心電困上の虚血変化を有さず，平均血玨も140/84 $\mathrm{mmHg}$ であり，降圧剤を服用している例はない，治療 としては主として理学療法にビタミン $\mathrm{B}_{12}$ 製凧，末梢循 環改善剈などの投与を行っている. 対照群には，ほぱ年 跲を一致させた主として事務作業に徒事する健常男性を 用いた. 統計学的検討は Student's “ $t$ ” test を用いた.

1. 神释伝導速度 (nerve conduction velocity, NCV) 検査は室温 $25 \sim 27^{\circ} \mathrm{C}$ の条件下て Medelec 社製 MS 91 を用いて，両手の尺骨神释，正中神経の MCV， SCV を測定したたたたし，手指の皮博温が $30^{\circ} \mathrm{C}$ 以下の場合

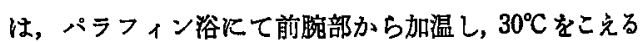
状態にした後に测定した，MCV は誘発筋電図のM波の 潜時差を利用する方法により，时関節〜手関節間で娜定 した. SCV は手指刺邀による順行性インパルスを加算 平均する順行性測定法により手指と手関節部の間, 手関 節部と时関節部の間の 2 か所で測定した（それそれ $\mathrm{SCV}_{\mathrm{F}-\mathrm{W}}, \mathrm{SCV}_{\mathrm{W}-\mathrm{E}}$ とする).

2. 電気味覚検查 ${ }^{3}$ (electrogustometry)

対象者に感冒症状のないこと，2時間以上哈㖶してい ないことを確認した後，冨田3)の方法に準して MEC 社 製電気味覚計 $610-\mathrm{M}$ を用いて，舌中央より $2 \mathrm{~cm}$ 外㑡の 舌縁部で左右鼓索神経領域の電気味覚域值を上昇法によ り測定した.すなわち，まず強い電気刺激を加え酸味に 似た味を確認させ，一度域值下に刺激を減らした後に馀 徐に上昇させ，最初に味を自覚する强さを测定，2回以 上一致した場合の刺激強度を電気味覚域値とした.さら 
Table 2. Mean, standard deviation and range of results of special examinations in patients with vibration disease $(n=20)$.

\begin{tabular}{|c|c|c|c|c|c|c|c|}
\hline \multirow{2}{*}{ Item } & & \multicolumn{3}{|c|}{ Jan. 1984} & \multicolumn{3}{|c|}{ Jan. 1985} \\
\hline & & Mean & SD & Range & Mean & SD & Range \\
\hline Age & $(y)$ & 55.25 & 5.22 & $44-63$ & & & \\
\hline Total operating time & (h) & 16,170 & 9,626 & $5,000-43,750$ & & & \\
\hline Finger skin temperature & $\left({ }^{\circ} \mathrm{C}\right)$ & 25.65 & 3.63 & $20.9-32.9$ & 26.06 & 4.98 & $17.7-33.0$ \\
\hline Nail-press test & (s) & 1.87 & 0.86 & $1.0-4.0$ & 2.22 & 1.21 & $1.0-4.8$ \\
\hline Pain sense thresholds & $(\mathrm{g})$ & 7.68 & 3.28 & $1.0-10.0$ & 7.45 & 2.77 & $1.0-10.0$ \\
\hline Vibratory sense thresholds $125 \mathrm{~Hz}$ & $(\mathrm{~dB})$ & 23.22 & 10.59 & $7.5-40.0$ & 22.69 & 7.90 & $10.0-40.0$ \\
\hline Hand grip strength & $(\mathrm{kg})$ & 29.54 & 6.85 & $16.0-44.3$ & 27.79 & 8.24 & $16.0-43.3$ \\
\hline Pinch power & $(\mathrm{kg})$ & 3.97 & 1.14 & $1.0-5.7$ & 3.58 & 1.08 & $1.0-5.0$ \\
\hline
\end{tabular}

Room temperature $16-22^{\circ} \mathrm{C}$.

に左右の域値の平均をとり被検者の成績とした。

3. 血清 dopamine- $\beta$-hydroxylase (DBH) 活性

午後 $1 \sim 2$ 時の間に採血し, 永津-Udenfriend 法 $^{7} \mathrm{~K}$ て血清 DBH 活性の测定を行った。

4. 心電图 R-R 間隔の変動係数 $\left(\mathbf{C V}_{\mathrm{R}-\mathrm{R}}\right)$

被検者を 15 分間以上安静仰卧位とした後，心電計と 接絰した MEC 社製 Autonomic R100を用いて 100 心 拍の R-R 間谝を記録しただちに变動係数 $\mathrm{CV}_{\mathrm{R}-\mathrm{R}}$ を算 出した.

特殊健診は労働省通達のつの方法に準して施行した．今 回の検討の対象とした検查項目としては，末梢循環障害 の指骠として手指中節背側の皮唐温，爪王迫後の充血時 間（爪压迫テスト值）を，末梢神経障害の指標と乙ては 痛覚域値, $125 \mathrm{~Hz}$ の振動敩域值を, 運動器障害の指標々 しては握力、ピンチカ（I-II指間）をとりあげた。な お，これらの値は常温下での成結を用い，健診時の室温 は 16 22 ${ }^{\circ} \mathrm{C}$ の範囲であった。神経伝導速度, $\mathrm{CV}_{\mathrm{R}-\mathrm{R}}$ は 1983 年 10 月， DBH 活性，電気味覚検査は 1984 年 9 10 月，特殊徤診は 1984 年 1 月拉よび 1985年 1 月に実施 した.

\section{III. 結 果}

特祙健部時の検查成績を Table 2 亿示す. 1984 年と 翌 1985 年の健診ではは注同様の成績が得られており， これら対象患者の障害の程度に著しい変化がおこってい ないことがらかがわれる．したがって，特殊健診の成績 を今回行った四つの神経機能険查の成責と比較すること すある程度意義のあることと考えられる.そこで，検查 の時間的ずれが，3，4か月以内であるように，神経层 学速度, $\mathrm{CV}_{\mathrm{R}-\mathrm{R}}$ 快 1984 年 I月, $\mathrm{DBH}$ 活性, 電気味覚
検査は 1985 年 1 月の健晾成績と比較することとした。 また，これらの検査成續は爪压迫テストの成續を除けば 手指背側皮唐温, 痛覚域値, $125 \mathrm{~Hz}$ の振動覚域值, 握 カ, ピンチカの各娭査成績の平均値はすべて岩田らの評 点基準8 の最高評点より悪い值を示しており，今回対象 とした振動障害患者が末梢神経機能，得環機能，筋力の 障害が進行していることを示している.

\section{1. 神経伝導速度}

Table 3 飞は対象患者之健常人の尺骨拈よび正中神経 の MCV, SCV の平均値, 標準偏差を示寸. 健常人と比 較すると対象患者では，すべての神経伝導速度において 低下して拈り，とくに尺骨神経の MCV 正中神経の $\mathrm{MCV}, \mathrm{SCV}_{\mathrm{F}-\mathrm{W}}, \mathrm{SCV}_{\mathrm{W}-\mathrm{E}}$ は有意低下していた。 た，測定不能の例するられた．Table 4 Kは各神経伝道 速度と 1984 年の特殊健診の検查項目の相関保数を示す. 正中神経，尺骨神経の $\mathrm{SCV}_{\mathrm{F}-\mathrm{W}}$ 之手指皮周温，爪正迫 テスト值の間，正中神経の $\mathrm{MCV}$ と爪圧迫テスト值の間 には有意な関連が双られ，末梢循環機能の低下が神経伝 導速度之りわけ手掌部の SCV の遅延に影響することが 考兄られた. 一方，痛覚，振動覚の域値上昇で示される 知敩異常や筇力低下と神経层導速度との間炕は有意な関 係灶みられなかった。 また，レイノー現象は対象患者に 高率にみられたために統計学的な検討はできなかった。

\section{2. 電気味覚検查 (electrogustometry)}

Table 5 кは舌尖中央より約 $2 \mathrm{~cm}$ 外側の舌縁の鼓索 神経領域て測定した電気味営域値を示す，対象患者の電 気味覚域值は年跲を対応させた健常人と此較して有意な 上异を示した $(p<0.01)$. しかしながら，自覚的に味 覚異常を訴えた例はみられなかった，電気咮覚域值と 1985 年の特殊健訅の㭘查項目との関係をみると,爪压迫 
Table 3. Nerve conduction velocities of patients with vibration disease and age-matched healthy controls.

\begin{tabular}{|c|c|c|c|c|c|}
\hline \multirow{2}{*}{ Conduction velocities } & \multicolumn{2}{|l|}{ Patients } & \multicolumn{2}{|c|}{ Controls } & \multirow{2}{*}{$\%$ of decreased NCV } \\
\hline & Mean \pm SD & $(n)$ & Mean $\pm S D$ & $(n)$ & \\
\hline \multicolumn{6}{|l|}{ Ulnar nerve } \\
\hline $\mathrm{MCV}$ & $51.69 \pm 4.40^{*}$ & (39) & $54.91 \pm 2.55$ & (14) & 36 \\
\hline SCV (finger-wrist) & $50.94 \pm 4.35$ & (37) & $53.46 \pm 2.90$ & (13) & 24 \\
\hline SCV (wrist-elbow) & $55.02 \pm 4.28$ & (37) & $56.76 \pm 4.43$ & (13) & 5 \\
\hline \multicolumn{6}{|l|}{ Median nerve } \\
\hline $\mathrm{MCV}$ & $55.81 \pm 2.94^{*}$ & (38) & $58.33 \pm 4.00$ & (13) & 5 \\
\hline SCV (finger-wrist) & $50.90 \pm 3.48^{* *}$ & $(40)$ & $54.91 \pm 3.78$ & (13) & 15 \\
\hline SCV (wrist-elbow) & $57.28 \pm 3.94^{*}$ & $(40)$ & $59.87 \pm 2.81$ & (15) & 28 \\
\hline
\end{tabular}

MCV : motor nerve conduction velocity, SCV : sensory nerve conduction velocity, NCV : nerve conduction velocity. NCV was judged as decreased if lower than mean $-2 \mathrm{SD}$ of the controls. $* p<0.05$, ** $p<0.01$, compared with controls.

Table 4. Correlation coefficients between nerve conduction velocities, $C_{\mathbf{R}-\mathbf{R}}$ and other functions.

\begin{tabular}{|c|c|c|c|c|c|c|c|}
\hline & \multicolumn{3}{|c|}{ Ulnar nerve } & \multicolumn{3}{|c|}{ Median nerve } & \multirow{2}{*}{$\mathrm{CV}_{\mathrm{R}-\mathrm{R}}$} \\
\hline & $\mathrm{MCV}$ & $S C V_{F-W}$ & $\mathrm{SCV}_{\mathrm{W}-\mathrm{E}}$ & $\mathrm{MCV}$ & SCVF-W & $\mathrm{SCV}_{\mathrm{W}-\mathrm{E}}$ & \\
\hline Finger skin temperature & -0.023 & $0.391^{*}$ & 0.150 & 0.270 & $0.438^{* *}$ & 0.276 & -0.213 \\
\hline Nail-press test & -0.107 & $-0.366^{*}$ & -0.301 & $-0.336^{*}$ & $-0.332^{*}$ & -0.297 & 0.034 \\
\hline Pain sense & 0.022 & 0.003 & 0.038 & -0.070 & -0.157 & -0.031 & 0.174 \\
\hline Vibratory sense & -0.079 & -0.205 & -0.247 & -0.265 & -0.143 & -0.016 & -0.033 \\
\hline Grip strength & -0.155 & -0.257 & -0.044 & 0.180 & -0.189 & 0.126 & -0.171 \\
\hline Pinch power & 0.044 & -0.204 & -0.120 & 0.013 & -0.133 & -0.169 & -0.041 \\
\hline
\end{tabular}

$* p<0.05, * * p<0.01$

Table 5. Electrogustatory threshold of patients with vibration disease and controls.

\begin{tabular}{|c|c|c|}
\hline & $\begin{array}{l}\text { Patients } \\
(n=18)\end{array}$ & $\begin{array}{l}\text { Controls } \\
(n=21)\end{array}$ \\
\hline $\begin{array}{l}\text { Electrogustatory } \\
\text { threshold (dB) }\end{array}$ & $11.72 \pm 8.01^{* *}$ & $3.76 \pm 4.07$ \\
\hline Age $\quad(y)$ & $55.78 \pm 5.11$ & $53.10 \pm 6.10$ \\
\hline
\end{tabular}

テスト值, 振動覚域値とは有意な正の相関がみられた (Table 6).

\section{3. 血清 DBH 活性}

DBH 活性は交感神経機能を表わすと考えられており 正常值は広い範囲に分布するが同一人ではほぼ一定した 值を示すといわれている9. Table 7 飞は血清 $\mathrm{DBH}$ 活
Table 6. Correlation coefficients between electrogustatory threshold, DBH activity and other functions.

\begin{tabular}{lcr}
\hline & $\begin{array}{c}\text { Electrogustatory } \\
\text { threshold }\end{array}$ & $\begin{array}{c}\mathrm{DBH} \\
\text { activity }\end{array}$ \\
\hline $\begin{array}{l}\text { Finger skin } \\
\text { temperature }\end{array}$ & -0.284 & -0.013 \\
Nail-press test & $0.587^{*}$ & -0.032 \\
Pain sense & 0.443 & 0.220 \\
Vibratory sense & $0.600^{* *}$ & 0.004 \\
Grip strength & -0.440 & -0.123 \\
Pinch power & -0.317 & -0.315 \\
\hline$* 0<0.05, * * \quad 0<0.01$ & &
\end{tabular}


性の值を示すが, 対象患者では健常人と比較して有意に $\mathrm{DBH}$ 活性が高値を示した $(p<0.05)$. しかし, 明らか な異常高値を示した例は 18 例中 2 例 $(62.1 \mathrm{U} / \mathrm{L}, 106.0$ U/L) であった. DBH 活性と 1985 年の特殊健診の検査 項目との相関をみても有意な関連はみられなかった (Table 6).

\section{4. 心要图 R-R 間隔の变動係数 $\left(\mathrm{CV}_{\mathrm{R}-\mathrm{R}}\right)$}

Table 8 には 15 分間以上安静仰卧後の $C_{R-R}$ を示 す. $\mathrm{CV}_{\mathrm{R}-\mathrm{R}}$ は加龄による影響を強くらけるので 44 54 歳, 55 65 歳の二つの年龄階級に分けても比較を行 。 た. その結果, 対象患者の $\mathrm{CV}_{\mathrm{R}-\mathrm{R}}$ は 44 54 歳におい ては煡常者より低い傾向 $(p<0.1)$ がみられ，55 65 歳 および全体では有意な低下がみられた。 また，自律神経 症状が出現する critical level といかれている103 $2 \%$ 未 満の例す 5 例 (25\%) にみられた. しかし, $\mathrm{CV}_{\mathrm{R}-\mathrm{R}}$ と 1984年の特殊健診の検查項目との間には関連性は認めら れなかった (Table 4).

\section{IV. 考 察}

振動障害は上肢を中心とした末梢神経障害，末梢循環 障害および運動器障害を主症状とするが, 本症患者が上 肢に限らず多彩な自覚症状を有することはよく知られて いる. そこで，四つの神経機能検査を用いて末梢神経機 能, 自律神経機能の客観的な評価を試みた，今回対象之 した振動障害患者 20 名は平均の TOT が 16, 170 時間, 平均振動工具使用年数が 15.2 年間々長期間の振動暴露 歴があり, レイノー現象陽性率, 自覚症状の愁訴率も高

Table 7. Serum dopamine- $\beta$-hydroxylase activities of patients with vibration disease and controls.

\begin{tabular}{lrrr}
\hline & $\begin{array}{r}\text { Patients } \\
(n=18)\end{array}$ & $\begin{array}{c}\text { Controls } \\
(n=26)\end{array}$ \\
\hline DBH activity (U/L) & $36.6 \pm 19.3^{*}$ & $25.1 \pm 13.6$ \\
Age & $(\mathrm{y})$ & $55.78 \pm 5.12$ & $49.35 \pm 6.18$ \\
\hline
\end{tabular}

$* p<0.05$, Mean \pm SD
く，また特殊健診の検查成績においても異常值が多く， Andreeva-Galanina 分類の第而期に相当するものと考 えられる.また，振動障害は振動工具の使用中止，治療 により改善することが知られているが，経過の遷延する 例も存在する ${ }^{11}$. 今回の対象患者に拈いて子振動工具使 用中止後の平均年数は 5.6 年間であり多くの㖶延化例が 含まれている，以下，個々の検查成績につき考察を加え る.

\section{1. 神経伝導速度}

振動障害患者の神経伝導速度に関する報告は数多くみ られるが12 17)，対象とした症例の一部あるいは測定した 神経の一部に異常がみられるとする報告が多い，荒記 5 14) 17 名のチェンソー使用者の正中神経, 後怪骨神 経の伝導速度を検討し，正中神経の手掌部 SCV，残差 潜時に执いて対照群と有意差がみられ，公導速度とレイ ノー現象とは関係がみられなかったとしている．鳥居 ら の MCV, SCV が有意に低下していたと報告している. 田辺 ${ }^{16)}$ は 16 名の振動病患者の正中神経の伝導速度を 測定し手掌部 SCV が有意低下しており末端部優位の 神経障害であるとしている. 久永 ${ }^{17)} 236$ 名の振動工具 使用者について検討を加点，正中神経，尺骨神経ともに $\mathrm{MCV}, \mathrm{SCV}$ の低下がみられるが，MCV より SCV の 低下が著明であり，また SCV の低下は末端部優位であ るとし，伀導速度の低下は末梢循環機能と有意に相関す ると報告している，今回のわれわれの成績に秃いてる， 尺骨神経の MCV 正中神経 の $\mathrm{MCV}, \mathrm{SCV}_{\mathrm{F}-\mathrm{W}}, \mathrm{SCV}_{\mathrm{W}-\mathrm{E}}$ は対象患者に颃いて有意に低下していた．乙かし，健常 人の平均值より $2 \mathrm{SD}$ 以上低下した伝導速度を示与割合 は 5〜36\%とそれ汪ど多くなく，一般的な異常低值とさ れる $45 \mathrm{~m} / \mathrm{s}$ 以下の伝導速度は 231 回の測定中に $\mathrm{SCV}_{\mathrm{F}-\mathrm{W}}$ で5回出現したにすぎないまた，すで報 告18)したように振動障害患者でみられた伝導速度の低下 は精尿病患者でみられるものより軽度であり明らかに病 的なすのであるとは考学られない，また，神経伝導速度

Table 8. Coefficient of variation of $R-R$ interval in ECG $\left(C V_{R-R}\right)$ in patients with vibration disease and controls.

\begin{tabular}{llllllll}
\hline \multirow{2}{*}{ Age $(\mathrm{y})$} & \multicolumn{4}{c}{ Patients } & & \multicolumn{3}{c}{ Controls } \\
\cline { 2 - 4 } \cline { 7 - 8 } & $N$ & $\mathrm{CV}_{\mathrm{R}-\mathrm{R}}(\%)$ & (mean age) & & $N$ & $\mathrm{CV}_{\mathrm{R}-\mathrm{R}}(\%)$ & (mean age) \\
\hline $44-54$ & 10 & $2.75 \pm 0.86$ & $(50.9)$ & & 27 & $3.39 \pm 0.88$ & $(49.2)$ \\
$55-65$ & 10 & $2.20 \pm 0.54^{*}$ & $(59.6)$ & & 19 & $3.14 \pm 1.12$ & $(59.1)$ \\
Total & 20 & $2.48 \pm 0.79^{* *}$ & $(55.3)$ & & 46 & $3.29 \pm 0.99$ & $(53.2)$ \\
\hline
\end{tabular}

\footnotetext{
* $p<0.05,{ }^{* *} p<0.01$, mean $\pm \mathrm{SD}$
} 
の低下は手指皮夙温，爪王迫テスト值と有意な相関がみ られ，このことは伝導速度低下の要因として末梢循環障 害が重要であることを示すと考劣られる.同様の所見は 久永 ${ }^{19)}$ 屯報告しており，振動障害においては神経障害と 循環障害が緊密に関連しながら進展するとの報告20) とひ 一致する. 他方, 神释伝導速度が知覚異常と関連しなか ったことは過去にむ報告されており ${ }^{13)}$ ，この原因として は神経伝導速度が有髄大径の神経線維の機能を反映する のに対して知覚異常は末梢の感覚受容器, 小径あるいは 無盏の神絓線維の機能す反映することが考えられる.

\section{2. 電気味営検查}

振動障害患者を対象として電気味覚揄查を施行した報 告はわれわれの検索範囲ではみあたらない，電気味覚域 值は加㱓による影響が強い211ため，年龄を対応させた健 常人を対照としたが，今回の成績では対象患者の電気味 覚域値は健常人上り有意化高值であることが示された. また, 電気味覚域值は爪匠迫テスト値, 振動覚域値と有 意な関連性がみられた.これらのことは今回対象とした 患者に健常人と比較して味覚異常が存在寸る可能性を示 すと考えられる. しかし, 電気味覚の異常は顔面神経麻 痺の他，糖尿病性神経障害 ${ }^{22}$ においても報告されている が, この異常が味蕾, 䔩索神経, 延䯣の孤束核から大腷 皮質に投射される味覚云導路のどの部位での異常による るのかは明らかではない。

\section{3. 血清 DBH 活性}

振動障害が自律神経系の異常, とくに交感神経系の六 進状態を背景に発症，進展するという報告23 25) がみら れる. 交感神経系の機能を直接的に評価する方法として は，血中カテュラミン濃度扎よび尿中カテコラミン排泄 量を測定する方法, あるいは血中 DBH 活性を測定する 方法がある. カテュラミンに関しては, 犬塚ら 23 , 颜 ら 24$)$ は振動障害患者の尿中カテコラミン排泄量が高值で あると報告し, 近藤ら ${ }^{25}$ は血獎ノルエピネフリン值が高 值であるとし，ともに交感神経系の機能充進がみられる としている. 今回の検討では交感神経機能の指標として 血清 DBH 活性を测定したが，血中 DBHの起源は交感 神経末端が主と推定されて括り，血中 DBH 活性の測定 は交感神経系の有力な機能検查法とされている9. これ までの報告26,27)では, 血清 DBH 活性は振動障害患者に おいてやや高い傾向にあるが有意差はみられなかったと されている. 今回のわれわれの成績では対象患者の血清 $\mathrm{DBH}$ 活性は健常者に比較して有意に高値であり交感神 経系の機能亢進状態にある可能性が示唆された.

4. 心電図 R-R 間隔の变動係数 $\left(\mathrm{CV}_{\mathrm{R}-\mathrm{R}}\right)$ 振動障害患者の副交感神経機能に関する報告は非常に
少ない，その原因の一つに副交感神経機能を評価する核 查法が少ないことが考えられる，近年，心拍の変動が心 血管系の迷走神経機能を反映することが明らかになり4， とくに安静時の心電図 R-R 間隔の変 動係数 $\left(\mathrm{CV}_{\mathrm{R}-\mathrm{R}}\right)$ を測定すれば副交感神経機能をある程度定量的に評価で きる5) とされている. 振動障害患者で，この $\mathrm{CV}_{\mathrm{R}-\mathrm{R}}$ を 検討した報告をみると，山河ら 272 は深呼吸時の心拍変動 が対照にくらべて有意に低下していたと報告し，小林 $5^{28)}$ は自律神経系の自覚症状の强い任らが $\mathrm{CV}_{\mathrm{R}-\mathrm{R}}$ の低 下が著しかったと報告している．今回のわれわれの検討 では $\mathrm{CV}_{\mathrm{R}-\mathrm{R}}$ が加龄の影響を強くらけることを考感し， 年龄を対応させた健常者との間で，44 54 歳，55 65 歳の二つの年跲階級に分けてる比較した。 その結果，い ずれにおいても対象患者の CV $\mathrm{C}_{\mathrm{R}-\mathrm{R}}$ が対照より低值であ り，55〜65 歳では有意差がみられた。 また，2\%末满 の低下例む25\%にみられた，また，すでに報告(18した ように $\mathrm{CV}_{\mathrm{R}-\mathrm{R}}$ 值の低下は特殊健診を受診した振動工具 使用者においてる認められており，これらのことは対象 患者の副交感神経系のうち迷走神経心䁍枝の機能低下 存在する可能性を示唆するすのと考えられる.このこと は原田 ${ }^{29}$ の振動障害患者の血獎中サイクリック GMP は低下しており安静時副交感神経機能の低下が考古られ るとする報告とす一致している。

振動障害が自律神経系, 内分泌系, 中权神経系江異 常の及ぶ全身性疾患であるとする考方方 ${ }^{303}$ には否定的な 見解31るあり定説は得られていない，今回，われわれが 実施した四つの神経機能検查において，対象とした振動 障害患者にはすべて健常者と比較して有意な盖異がみら れ機能異常が存在することが示唆された.しかし，対象 とした振動障害患者が不均一な集団である点，加踰など の他の要素が加わりやすい経過遷延例11が多く含まれる 点, また対照群が森林労働者でない点を考亚すれば、こ れらの差異が振動障害自体に起因するすのとは断定でき ない.しかしながら，神経伝導速度の遅延，味覚域值の 上昇, 血清 $\mathrm{DBH}$ 活性の高値, $\mathrm{CV}_{\mathrm{R}-\mathrm{R}}$ の低下か対象患 者においてみられたことは，振動障害の病像を検討する らえで，これらの検查が有用であることを示唆すると考 えられる.

\section{V. 秸 語}

Andreeva-Galanina 分類の第而期に相当する振動障 害患者 20 名を対象に上肢の神経层導速度，電気味覚域 值, 血清 DBH 活性, 心電図 R-R 間隔の変動俰数を測 定し，特殊健診時の検査成續とも比較検討し，以下の結 果を得た。 
(1) 対象患者の尺骨神経の MCV, 正中神経の MCV, $S C V_{F-W}, S C V_{W-E}$ は健常人と此較して有意に低下して いた．また，神経伝導速度は手指皮庙温，爪圧迫テスト值 と有意に相関し末梢循璒障害との関連性が考古られた。

(2) 対象患者の跂索神経領域の電気味覚域値は健常人 に比較して有意に上昇していた.

（3）対象患者の血清 DBH 活性は健常人より有意に高 值でり，交感神释系が機能㐫進状態にある可能性が示 唆された.

(4) 対象患者においては, 心電図 R-R 間隔の变動係 数恃年龄を対応させた健常人と比較して 55 65 歳にお いて有意に低下しており，副交感神経機能のらち迷走神 経心䁍枝の機能低下が存在する可能性が示唆された。

（5）これらの所見は，今回対象とした振動障害患者に 健常人と比較して末梢神経系, 味覚および自律神経系に 及ら゙異常が存在することを示唂すると考えられ，振動障 害の病像を検討する際にこれらの検查が有用であると考 えられた。

稿を柊光るにあたり，ご校閲を胞わった笠松隆洋先生，本研 究に㗨しこ協力を睗わった国保すさみ病院職員の皆様方に深く 感謝の意を表します．なお，本研究の要旨の一部は，第 57 回和 よび第 58 回日本産業衛生学会に和いて甡表した。

\section{文献}

1）山田信也.チェンソー（自動鋸）の振動による手指の蓄 白現象について. 荹業医学 1965；7：211-212.

2）的場佰孝. 振動病に関する最近の知見. 日本医事新報 1983; 3096:3-8.

3）冨田 蒐. デシベル単位の䉓気味営計. 医学のあゆみ $1971 ; 77: 691-696$.

4) Wheeler $T$, Watkins PJ. Cardiac denervation in diadetes. $\mathrm{Br}$ Med $\mathrm{J} 1973 ; 4: 584-586$.

5）照山 茂，清水光行，笹生文雄汪か. 糖尿病性自律神経 障害の定量的分析火関する研究. 糖尿病 $1979 ; 22 ： 627-$ 634.

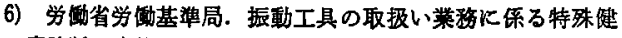
康视断の実施手技について，1975；基発609号.

7) Nagatsu T, Udenfriend S. Photometric assay of dopamine- $\beta$-hydroxylase activity in human blood. Clin Chem $1972 ; 18: 980-983$.

8）岩田弘钽. 振動症候群. 東京: 近代出版，1978：147148.

9) 新保慎一郎. ドーパン $\beta$ ハドロキシンース(DBH). 日本臨床 1982；40 (秋孝臨時增刊号) : 607-610.

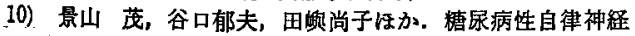
障害における critical level一心電図 R-R 間隔の変動保
数による一. 自律神経 $1983 ； 20 ： 76-80$.

11）的場佰孝，板家守夫，戸鴆裕徳. 遥延化した臨床維過を とる控動病患者の臨床像.日内会誌 $1981 ； 70: 50-56$.

12) Seppălăinen AM. Peripheral neuropathy in forest workers-a field study. Work Environ Health $1972 ; 9: 106-111$.

13）那頁吉郎. 振動工具使用者の振動覚々正中神経知覚云導 速度について. 産業医学 $1977 ; 19: 452$.

14) Araki S, Honma T, Aoyama T. Peripheral nerve conduction velocities in chain-saw operators. Jpn J Ind Health $1976 ; 18: 516-520$.

15）鳥居順三, 高坂公博, 今西速雄. chain saw 使用者に 扣活る末梢神経障害. 日本医事新報 1978；2829：32-34.

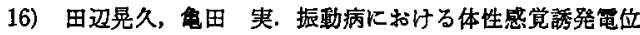
之神経云尊速度. 臨床脳波 $1979 ； 21: 324-328$.

17）久永 孟. 振動工具使用者の末梢神経云導速度に関する 研究. 㢈業医学 1982；24:284-293.

18）佐々木秀行，藤本特三，菊岡弘芳泳加。指動障害患者の 神経譏能一糖尿病性神経障害患者之の比較一. 座業医学 $1984 ; 26: 780$.

19）久永 孟. 搙動工具作菜者の末梢神経障害に対する末梢 循猿障害の関与について. 産業医学, 1982; $24: 803$.

20）宫下和久. チェンソー棇取报い時間之症状発現捛よび症 状相関に関する研究. 産業医学 1983；25：483-491.

21）富山紘彦，冨田 宽，奥田哥雄。電気味覚の正常値. 日 耳要 $1971 ; 74: 1580-1587$.

22）里神永一，三家登喜夫，近藤 溪ほか，煻尿病患者にお

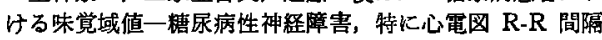
の変動係数との関連性について一。糖尿病 1986；29： 197-203.

23）犬塚佑子，加地 浩，斉藤和雄，振動障害になける尿中 および血漿中カテニールフミンの検討. 産業医学 1985; $27: 644$.

24）畧 博，松永純子，百瀨義人ほ加，振動病患者の尿中 カテコラミン牧よび 17-OHCS 排沘量. 産業医学 1985; $27: 645$.

25）近藤弘一，原田規章，木村 振動障害患者の自律神 経機能について(1) 寒冾負荷による血漿 NE，E 值の变動。 第 58 回日本産業衛生学会講演集, $1985: 306-307$.

26）仮井文彦，篗原幸人，浅葉義一. 白万万病患者における 血清 dopamine- $\beta$-hydroxylase 活性値. 眽管学 1975; $15: 577$.

27）山河 泉，原田規章，木村 度. 振動帟害検猃に拈ける 自律神経譏能評価の試み一心電图 R-R 間隔の变動と血清 $\mathrm{DBH}$ 活性一. 産業医学 $1982 ; 24: 804$.

28）小林章雄，中川武夫，宮尾 克的。振動障害者の自律 神経機能の検討一心電図 R-R 間隔の変動. 廒業医学 $1982 ; 24: 803$.

29）原田規章，近藤弘一，木村 振動障害患者の自律神 経機能について(2) 寒冷目荷に上る血漿環状ヌクレオチドの 変動. 産業医学 $1985 ; 27: 647$.

30) Matoba $T$, Kusumoto $H$, Mizuki $Y$ et al. Clinical features and laboratory findings of vibration disease: A review of 300 cases. Tohoku J Exp Med 1977; $123: 57-65$.

31）土生久作. 振動障害. 東京 : 六法出版社, 1984.

著者への通信先： 佐々木秀行, $\mathbf{7} 640$ 和歌山市七番丁 1 番地 和歌山県立医科大学第一内科 Reprint requests to First Department of Medicine, Wakayama University of Medical Science, 1, 7-Bancho, Wakayama, 640 Japan (H. Sasaki) 